\title{
Factors Affecting Faculty Attitude for Adopting Online Learning at Aljouf University, Saudi Arabia
}

\author{
Salim M. Alanazy ${ }^{1}$ \\ ${ }^{1}$ Faculty of Education, Aljouf University, Skaka, Saudi Arabia \\ Correspondence: Salim M. Alanazy, Faculty of Education, Aljouf University, Skaka, Saudi Arabia. E-mail: \\ salanazy@ju.edu.sa
}

Received: October 4, 2017

Accepted: October 18, 2017 Online Published: October 24, 2017

doi:10.5539/jel.v7n1p154

URL: https://doi.org/10.5539/jel.v7n1p154

\begin{abstract}
This study aims to take an initial step toward investigating the readiness of faculty members for adopting online learning at Aljouf University, a Saudi newly established university. Participants $(n=156)$ were asked to complete a Web-based questionnaire that starts with eight demographic questions and has four other parts: attitude toward online learning, computer self-efficacy, attitude toward technology, and computer anxiety. The results demonstrate that faculty members show positive attitudes toward online learning $(\mathrm{M}=3.03, \mathrm{SD}=0.45)$. They also showed a slight high computer self-efficiency $(\mathrm{M}=2.92, \mathrm{SD}=0.40)$, positive attitudes toward technology $(\mathrm{M}=3.10$, $\mathrm{SD}=0.33)$, and a low level of computer anxiety $(\mathrm{M}=1.05, \mathrm{SD}=0.38)$. Finally, the results reveal that among the demographic variables, only the nationality of the participants and their experience with online learning had a significant effect on their attitude toward online learning. The study concluded with providing a number of recommendations for application and future studies.
\end{abstract}

Keywords: computer anxiety, computer self-efficacy, faculty attitude, higher education, learning strategies, online learning

\section{Introduction}

\subsection{Statement of the Problem}

With a vast majority of populations continuously connected to the Internet, many educational institutions across the world are tapping the potential of imparting online education in different sectors. These developments in the field of online learning and teaching can be seen across different sectors of higher education, more significantly in the area of distance education by creating new avenues for improvements in distance learning programs. These developments in on-campus and distance education programs are also attributed to the educational value of digital and networked learning tools (Milheim, 2012). In Saudi Arabia, e-learning is considered to be a new process (Al-Harbi, 2011) introduced at the undergraduate level teaching-learning context. In addition, most of the universities in Saudi Arabia are slowly progressing on par with the global trends of focusing on incorporating e-learning into the existing curriculum of on-campus and distance education programs (Al-Khalifa, 2009). At Aljouf University, a newly established university that is currently the only university serving Aljouf region of Saudi Arabia, the Deanship of E-learning and Distance Education (DELDE) has been established with a mission of leading and facilitating the university movement toward online education.

In 2015, the university's plan was to implement online learning in the regular programs, as well as move its distance education programs from an independent correspondence form to an online learning form after launching the Blackboard software. The targeted learners were those students who enrolled in the on-campus programs, as well as those who registered in the distance education mode. DELDE is required to support the learners and faculty, provide training programs, and monitor the effectiveness of online courses for enhancing the teaching-learning process. As a result, DELDE started monitoring the progress of the initial phases of introducing e-learning to the teaching-learning process. One of the first steps that DELDE has taken was to investigate the faculty readiness for online learning. Faculty readiness to embrace online learning is a critical component of quality online education. The success of the instructors' readiness in online learning includes the willingness to prepare, design, and facilitate effective courses within an online environment. 
However, the hesitancy among many individuals to discard traditional and outdated technology that is less sophisticated and easy to operate has been a major constraint for the new technology to penetrate into various professional fields. For decades, studies were undertaken to examine the knowledge and skill gaps of university teachers in technological pedagogical content knowledge (Thompson Manning, 1987). According to Rogers (1995), if the educational system is determined to achieve a meaningful use of technology in instruction, the success of the use of technology in the educational environment is related to the attitude of the teaching staff. Undeniably, teachers play an important role in the educational system and in the implementation of instructional strategies and tools. Their attitude toward technology is a key determinant for the successful use of technology in any form of educational setting. Summers (1990) confirmed that the teachers' present attitudes, skills, and work habits drive their acceptance. In their relational survey model study, Celik and Yesilyurt (2013) identified three factors as important predictors of teacher attitude toward using computer-supported education, including attitude to technology, perceived computer self-efficacy, and computer anxiety.

This study aims to investigate the attitude of Aljouf University faculty members toward applying online learning. It also examines different aspects that may affect their attitude including computer self-efficacy, attitude toward technology, and computer anxiety (Arani, 2016; Brosnan, 1998; Busch, 1995; Celik \& Yesilyurt, 2013; Paraskeva, Bouta, \& Papagianni, 2008; Webster \& Martocchio, 1992).

\subsection{Questions of the Study}

The study determined the faculty attitude toward applying online learning at Aljouf University in Saudi Arabia. Specifically, it answered the following questions:

1) What are the attitudes of faculty toward online learning at Aljouf University?

2) Are there significant relationships between faculty attitude toward online learning, and their computer self-efficacy, attitude toward technology, and computer anxiety?

3) Are there significant relationships among the faculty computer self-efficacy, attitude toward technology, and computer anxiety?

4) Is there a significant difference in attitude toward online learning, computer self-efficacy, attitude toward technology, and computer anxiety of faculty at Aljouf University in terms of their gender, age, nationality, degree held, and experience in online learning?

\subsection{Rationale and Significance of the Study}

The study aims to help the decision maker at Aljouf University in the process of introducing online learning to ensure the good implementation. Identifying the state of the faculty attitude toward this new type of teaching and the factors that may affect their attitudes can help provide a number of recommendations to improve their attitude and subsequently their performance in online learning environments.

\subsection{Theatrical Framework}

This study is based on the theoretical foundations of Diffusion Theory (Roger, 1995) and Technology Acceptance Model (Davis, 1998). According to Rogers (1995), if the educational system is determined to achieve a meaningful use of technology in instruction, the success of the use of technology in the educational environment is related to the attitude of the teaching staff. The study is also based on the review of literature related to the factors effecting faculty attitude toward online learning (Arani, 2016; Brosnan, 1998; Busch, 1995; Celik \& Yesilyurt, 2013; Paraskeva et al., 2008; Webster \& Martocchio, 1992).

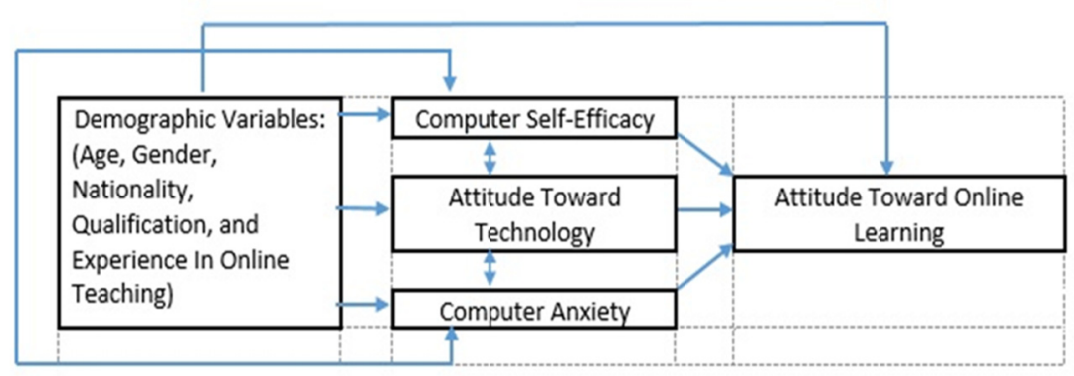

Figure 1. Conceptual Framework 


\section{Methodology}

This study is a descriptive correlation quantitative study. It describes the current level of attitude of the faculty members toward online learning. Relationships, among attitude toward online learning, computer self-efficacy, attitude toward technology, and computer anxiety of faculty, were also determined and described.

\subsection{Study Plan}

The Web-based survey was sent via the Information Technology (IT) department to all faculty members of Aljouf University ( $\mathrm{N}=732)$ in Spring semester 2016. This study identified the participants to be those holding either a master or doctorate degree, and 156 members met the inclusion criteria and chose to participate in the study. In identifying relevant demographic information of the participants, the following items were included: age, gender, nationality, qualification degree held, and experience in online learning. The characteristics of the participants are shown in Table 1.

Table 1. Characteristics of the participants

\begin{tabular}{cccc}
\hline & Characteristics & Frequency & Percent \\
\hline \multirow{2}{*}{ Gender } & Male & 98 & 62.8 \\
& Female & 58 & 37.2 \\
& 38 and less & 57 & 36.8 \\
Age & $39-45$ & 68 & 43.9 \\
& $46-54$ & 22 & 14.2 \\
& 55 and more & 8 & 5.2 \\
Nationality & Saudi & 32 & 20.9 \\
& Non-Saudi & 121 & 79.1 \\
Qualification & Master & 118 & 77.1 \\
& Doctorate & 35 & 22.9 \\
Experience with online & Have experience & 60 & 38.5 \\
learning & No experience & 96 & 61.5 \\
\hline
\end{tabular}

\subsection{Instruments}

To accurately achieve the objectives of this study, a set of four constructs were developed. The survey started with collecting the needed demographic information regarding the participants. The second part includes the attitude toward online learning scale (16 items) developed by the researcher to measure the faculty members' attitudes toward applying online learning. The third part contains the perceived computer self-efficacy scale (Askar, 2001) to measure the computer self-efficacy of the faculty members. In the fourth part, the technology attitude scale (Yavuz, 2005) was used to measure the faculty members' attitudes to technology attitudes. Finally, the computer Anxiety Scale (modified from Ceyhan \& Namlu, 2000) was used to measure the faculty members' levels of Computer Anxiety.

For the second, fourth, and fifth parts of the survey, participants were asked to rate their degree of agreement on a 5-point Likert scale for each item as follows: 1) strongly disagree to 5) strongly agree. On the other hand, participants were asked to rate their responses for computer efficacy with 1) always; 2) usually; 3) sometimes; 4) rarely; and 5) never. The reliability of the questionnaire was statistically tested. The Chronbach reliability alphas of the four factors were 0.86 for attitude toward online learning, 0.81 for computer self-efficacy, 0.73 for technology attitude, and 0.80 for computer anxiety. The items in the questionnaire were translated from English to Arabic using a back-and-forth translation method. Four faculty members from the college of education, who mastered both the Arabic and the English languages, participated in the process of the survey translation.

\subsection{Statistical Analysis}

The Statistical Package for Social Sciences (SPSS20) was used to generate descriptive and inferential statistics at a significance level of 0.05 . The frequencies and mean were reported for each variable. T-test and ANOVA were also used to examine the relationships between the instructors' attitude toward online learning and the 
demographic variables. On the other hand, Pearson $r$ correlation was used to examine the relationships between attitude toward online learning and computer self-efficacy, attitude toward technology, and computer anxiety. Pearson $\mathrm{r}$ correlation was also used to investigate the relationships among the three independent variables.

\section{Results}

From the data collected and statistics performed, the study yielded the following results and analyses. The results in Table 2 demonstrate that faculty members show a positive attitude toward online learning $(\mathrm{M}=3.03, \mathrm{SD}=0.45)$. It also reveals that they have a positive attitude toward technology $(\mathrm{M}=3.10, \mathrm{SD}=0.33)$. In terms of their computer self-efficiency, the results show that faculty members have a slightly high computer self-efficiency $(\mathrm{M}=2.92, \mathrm{SD}=0.40)$. Finally, the results show that faculty members reported a low level of computer anxiety $(\mathrm{M}=1.05, \mathrm{SD}=0.38)$. As shown in Table 3, there is a stromg positive relationship among online learning attitude, computer efficacy, and technology attitude; however, there is a negative relationship between computer anxiety and the other three factors. The results indicate that the gender, qualification, and age of the participants yielded near equal in terms of their receptivity in computer efficacy, technology attitude, online learning attitude, and computer anxiety (Tables 4 and 5). Moreover, among the readiness constructs, technology attitude was not affected by any demographic profiles, age, gender, qualification, nature of work, or years of traditional teaching. However, the results reveal a number of significant relationships between the demographics and the readiness of the participants. The participants' nationality has an effect on computer efficacy, online learning attitude, and computer anxiety. Experience in online learning, likewise, had an effect on the attitude toward online learning and computer efficacy.

Table 2. Mean and standard deviation for the four readiness factors

\begin{tabular}{ccc}
\hline Variables & Mean & SD \\
\hline Online learning attitude & 3.03 & 0.45 \\
(1, negative attitudes toward; 5, positive attitudes toward online learning $)$ & & 0.40 \\
Computer self-efficacy & 2.92 & 0.33 \\
$(1$, low computer self-efficacy; 5, high computer self-efficacy $)$ & 3.10 & 0.38 \\
Technology attitude & & 1.05 \\
Computer anxiety & \\
$(1=$ low computer anxiety, 5=high computer anxiety $)$ & \\
\hline
\end{tabular}

Table 3. Correlation matrix of readiness constructs

\begin{tabular}{|c|c|c|c|c|c|}
\hline \multicolumn{2}{|c|}{ Variables } & $\begin{array}{c}\text { Online Learning } \\
\text { Attitude }\end{array}$ & $\begin{array}{c}\text { Computer } \\
\text { Self-Efficacy }\end{array}$ & $\begin{array}{c}\text { Technology } \\
\text { Attitude }\end{array}$ & $\begin{array}{c}\text { Computer } \\
\text { Anxiety }\end{array}$ \\
\hline $\begin{array}{c}\text { Online Learning } \\
\text { Attitude }\end{array}$ & $\begin{array}{c}\text { Pearson } \\
\text { Correlation }\end{array}$ & 1 & & & \\
\hline Computer Self-Efficacy & $\begin{array}{c}\text { Pearson } \\
\text { Correlation }\end{array}$ & $0.485^{* *}$ & 1 & & \\
\hline Technology Attitude & $\begin{array}{c}\text { Pearson } \\
\text { Correlation }\end{array}$ & $0.584 * *$ & $0.341^{* *}$ & 1 & \\
\hline Computer Anxiety & $\begin{array}{c}\text { Pearson } \\
\text { Correlation }\end{array}$ & $-0.715-* *$ & $-0.517-* *$ & $-0.494-* *$ & 1 \\
\hline
\end{tabular}

\footnotetext{
**. Correlation is significant at the 0.01 level (2-tailed).
} 
Table 4. T-tests results for differences based on gender, nationality, qualification, and experience with online learning

\begin{tabular}{lcccccccc}
\hline \multirow{2}{*}{\begin{tabular}{l} 
Variables \\
\cline { 2 - 7 }
\end{tabular}} & \multicolumn{2}{c}{$\begin{array}{c}\text { Online Learning } \\
\text { Attitude }\end{array}$} & \multicolumn{2}{c}{ Computer Efficacy } & \multicolumn{2}{c}{ Technology Attitude } & \multicolumn{2}{c}{ Computer Anxiety } \\
\cline { 2 - 8 } & $T$ & $P$ & $T$ & $P$ & $T$ & $P$ & $T$ & 0.44 \\
\hline Gender & 0.46 & 0.65 & 0.46 & 0.65 & 0.48 & 0.63 & 0.66 \\
Nationality & 2.79 & 0.01 & 2.46 & 0.02 & 0.82 & 0.41 & 2.77 & 0.01 \\
Qualification & 0.11 & 0.91 & 1.66 & 0.10 & 1.55 & 0.12 & 0.44 & 0.66 \\
$\quad \begin{array}{l}\text { Experience with Online } \\
\text { Learning }\end{array}$ & 2.05 & 0.04 & 3.10 & 0.00 & 0.12 & 0.91 & 1.84 & 0.07 \\
\hline
\end{tabular}

Table 5. ANOVA results for differences based on age

\begin{tabular}{cccccccccc}
\hline \multirow{2}{*}{ Variables } & \multicolumn{2}{c}{$\begin{array}{c}\text { Online Learning } \\
\text { Attitude }\end{array}$} & \multicolumn{2}{c}{ Computer Efficacy } & \multicolumn{2}{c}{ Technology Attitude } & \multicolumn{2}{c}{ Computer Anxiety } \\
\cline { 2 - 10 } & $F$ & $P$ & $F$ & $P$ & $F$ & $P$ & $F$ & $P$ \\
\hline Age & 0.26 & 0.61 & 1.67 & 0.18 & 0.91 & 0.55 & 1.20 & 0.31 \\
\hline
\end{tabular}

\section{Discussion}

The deanship continues the mission of supporting colleges to deliver quality education by implementing online learning in traditional courses. To achieve this mission, the deanship began with the organization of training programs for faculty members. However, the use of latest technologies poses many challenges to DELDE and thus requires a comprehensive strategy to educate the faculty and students on the effective use of online learning technologies. Because technological progress facilitates life in a large variety of contexts, from science to education, and is often supported by computers (Celik \& Yesilyurt, 2013), introducing online learning and teaching courses can trigger a mixed response in faculty members. The results of this study can give more insight into the success of the mission of ensuring a quality teaching and learning environment.

The results demonstrate that faculty members show a slightly high computer self-efficiency, positive attitudes toward technology and online learning attitude, and a low level of computer anxiety. The result also reveals significant relationships among the four factors: online learning attitude, computer efficacy, technology attitude, and computer anxiety. This result aligned with the finding from previous studies (Brosnan, 1998; Celik \& Yesilyurt, 2013; Simsek, 2011).

The results of the current study indicate that faculty members show positive attitudes toward online learning. The integration of computer-based instructional methods in the learning and teaching process improved the quality of distance education programs. It reduced the amount of physical labor and strain that prevailed in the traditional distance learning programs. In addition, computer technology fastened the pace of correspondence between the teachers and the students, thus eradicating many barriers that were obstacles in the communication processes. However, research in the field of e-learning has proven that self-efficacy is an important factor because the personal beliefs and motivational conditions are expected to have an impact on the actual computer performance (Imhof, Vollmeyer, \& Beierlein, 2007). The quest among the administrators and academicians to progress with the current trends and improve the quality of education through innovative methods of classroom instruction being the sole reason to embrace the new technology into the classroom has witnessed mixed reactions in the teaching community. Often, the administrators and the curriculum designers are quick to recommend computer and Web-based technology for classrooms across the world by forgetting the fact that many teachers lack expertise in the use of technology. Because the latest computer-related educational software constitutes too many tools, it poses problems for the teachers during the initial stages. As individuals progress from the initial forethought phase of goal setting and strategic planning to the reflection phase, they are expected to improve on their self-efficacy and reach to a stage where they can self-evaluate the reasons for success and failures of technological instruction. However, it was observed that the university teachers are still struggling with the challenges associated to understanding an increasing array of technologies and differentiating which ones are relevant for online instruction (Witt, 2012). 
However, earlier research in the technology-integrated learning field outlines that there are constraints that often impede the progress of e-learning. Despite these advancements in the use of computer applications and web technology, teachers' views and abilities concerning technology have not moved with the pace of these developments (Strickland, 2006). The need to integrate computers in learning has become indispensable but is often accompanied by constraints. When individuals are instructed to make use of computer applications specifically designed for enhancing learning in the classroom, they may display anxieties and reactions. A complex combination of negative responses, which includes fear, worry, agitation, and apprehension (Saadé \& Kira, 2009), in the use of computer applications can be a cause of anxiety in the new and untrained generation of teachers working in different fields of education.

The results also demonstrate that faculty members at Aljouf University show a slightly high computer self-efficiency. Computer efficacy, or the belief in one's capabilities to organize and execute the courses of action required to produce the given attainments (Bandura, 1997), has an effect on teachers in any department. Self-efficacy is an important factor that is positively related to performance during computer training (Webster \& Martocchio, 1992) and determines the success of computer learning (Chung, 2012). Bandura (1997) defines self-efficacy as an individual's self-assessment of his/her own capabilities to organize and validate courses of action that are required to attain designated types of performance. He further states that self-efficacy is influenced by an individual's confidence in accomplishing a task with whatever skills one possesses. Computer self-efficacy is considered to be a particular type of self-efficacy (Nordin, 2005), which may be needed for acquiring computing skills (Miura, 1987). Computer self-efficacy is also defined by Compeau and Higgins (1995) as the belief of an individual's ability and capability to accomplish tasks by applying computer technology. The acceptance and rejection of technology is based on Bandura's theory of self-efficacy which refers to the belief in one's ability to perform a particular behavior (Bandura, 1986). Additionally, many studies have demonstrated the effect that computer self-efficacy has on enhancing performance and the technological expertise of employees, thus, reducing computer-induced anxiety. According to Papagianni (2008), a major constraint in computer-integrated instruction is that individuals who consider themselves as incompetent in computers are less likely to use them. They argue that self-esteem is a critical factor for success and depends on intelligence and competency levels of an individual. As a result, the level of faulty computer self-efficacy needs to be improved for the successful implementation of online learning at Aljouf University.

On the other hand, technology is a boon to education, and traditional approaches are enhanced by using the latest technology in teaching. Attitude toward technology is a determining factor in teacher readiness for online learning (Celik \& Yesilyurt, 2013). In this highly advanced technology era, it is common for teachers to be adaptive and receptive of new technologies. Thus, Tezci (2010) stressed that their professional attitude motivates them to use these changes to enhance the quality of teaching and learning. Attitude is a pattern of behavior tendencies or anticipatory readiness, predisposition to adapt to social situation, or simply it is a response to social stimuli that have been conditioned. Hence, attitude plays significant role in determining people acceptance and rejection of an idea or a task. The result of the current study indicated that the faculty members at Aljouf University expressed positive attitudes toward technology, which is expected to help the successful implementation of online learning. According to Coppola (2004), technology integration in learning is a challenging task because teachers have to believe in the beneficial aspects and should foresee the value of technological integration in the regular instructional process. Kluever et al. (1994) also concluded a teacher's attitude toward technology determines the successful implementation of using technology in education.

The results also indicate that the faculty members show low computer anxiety. Computer anxiety is another factor that affects the integrating technology with higher education. Busch (1995) asserted that positive attitudes toward computers and lower computer anxiety levels could be important factors in supporting the ability to learn computer skills for teaching and learning. This present study shows that technology attitude has an effect on computer anxiety, because when an attitude of belief and agreement with a certain task is maintained, more success is perceived and anxiety is reduced (Brosnam, 1998).

The result also reveals significant relationships between attitude toward online learning, computer efficacy, technology attitude, and computer anxiety. It also showed significant relationships among the three independent factors: computer efficacy, technology attitude, and computer anxiety. This result aligned with the finding of a previous study by Celik and Yesilyurt (2013). Attitude to technology, perceived computer self-efficacy, and computer anxiety are important predictors of teachers' attitude toward using computer-supported education. In the era of global technology, employees are often expected to upgrade their knowledge and skills in the uses of computer devices. According to Gibson (1996), there is a need for an assessment to detect adult learners who might be potentially at risk of failing in using computer technology in their distance learning. Simsek (2011) 
argued that reducing computer anxiety and increasing the computer self-efficacy is necessary to learn computer skills. A computer-based teaching program requires teachers to progress from their traditional methods of chalk and talk to a more state-of-the-art arena of applying computer applications to the teaching-learning process.

According to the results of this study, nationality appears to play an important role in a faculty member's level of computer self-efficiency, attitude toward online learning, and computer anxiety with online learning. The success of e-learning courses depends on the beliefs, attitudes, and technical knowledge that teachers bring to the e-learning environment. The results reveal that $80 \%$ of the participants were non-Saudi, and the nationality of the faculty members had a significant effect on three of four readiness constructs. The faculty members come from various countries and bring their 1) availability and access of computers; 2) availability of curriculum materials; 3) beliefs; 4) technological and content knowledge; and 5) technical, administrative, and peer support (Lowther, Inan, Daniel Strahl, \& Ross, 2008). Further, Cuban et al. (2001) explain that the teachers' adaption of technology is linked to their experiences retained from their country of origin regarding what constitutes the best methods of teaching and learning. However, the Saudi faculty members showed better level of readiness for online learning in three of the readiness aspects: computer self-efficacy, attitude toward online learning, and computer anxiety. Because most of the non-Saudi faculty members came from Arab countries, such as Egypt, Jordan, and Sudan, this result can be explained by the different financial statuses of Saudi Arabia and those countries. In 2017, 200 billion Saudi Riyal was assigned for education. This number makes $22 \%$ of the entire Saudi national budget (Ministry of Finance, 2016).

On the other hand, the results indicate that gender has no significant effect on any of the readiness constructs. Both female and male faculty members have similar perception ratings for every readiness construct. Gorder (2008) explained that gender exhibits no difference in the means of technology use perception. Experience with online learning has a significant effect on a faculty member's attitude toward online learning and their computer self-efficacy. A teacher's experience can influence his or her online readiness and can filter in its success because experiences gained over time enhance knowledge, skills, and productivity. According to Fives (2003), lack of confidence caused by lack of experience in teachers can result to stress. Hence, as the teaching experience increases, the corresponding efficacy increases.

\section{Conclusion and Recommendation}

The objective of this study was to investigate faculty member attitude toward online learning at Aljouf University. The results indicate that faculty members at JU show positive attitudes toward online learning. They also show a slightly high computer self-efficiency, positive attitudes toward technology, and a low level of computer anxiety. The findings also suggest that the faculty attitude toward online learning is highly correlated with their computer efficacy, attitude toward technology, and computer anxiety. In other words, for faculty members to be ready for successful implementation of online learning, they have to have a high level of computer efficacy, a positive attitude toward technology, and a low computer anxiety. Any change of factor can affect the others and consequently affect the readiness of implementing online learning. As discussed by Isleem (2003), computer attitude is a significant predictor of technology use in an instructional environment. The attitude and emotional investment of teachers also create the meaning they bring to technological changes. Therefore, integrating technology into education constitutes changes to the teaching style, which may need changes in the attitude of teachers (Albion, 2002). As a result, the recommendations of the study include that although introducing online education, pedagogical benefits should be emphasized. Moreover, guidance and assistance should be provided as the teachers provide their own experiences and beliefs. The result of the present study suggested that experience with online learning has a significant effect on faculty members' attitude toward online learning and their computer self-efficacy. It also indicated that Saudi faculty members showed higher level of attitude toward online learning than non-Saudis. They also showed a better level of computer self-efficacy and computer anxiety. Because most of the non-Saudi faculty members came from Arab countries such as Egypt, Jordan, and Sudan, this result can be explained by the different financial status of Saudi Arabia and those countries. This result also may suggest more awareness and training on computer skills, integration of technology in education, and online teaching need to be organized for non-Saudi faculty members. Future studies need to be done to investigate the factors affecting the readiness of non-Saudi faculty members toward online learning at Aljouf University.

\section{Acknowledgments}

The author would like to thank the Deanship of Scientific Research at Aljouf University for their support in this research. 


\section{References}

Albion, P. R., \& Ertmer, P. A. (2002). Beyond the foundations: The role of vision and beliefs in teachers' preparation for integration of technology. Tech Trends, 46(5), 34-38. https://doi.org/10.1007/BF02818306

Al-Harbi, K. A.-S. (2011). e-Learning in the Saudi tertiary education: Potential and challenges. Applied Computing and Informatics, 9(1), 31-46. https://doi.org/10.1016/j.aci.2010.03.002

Al-Khalifa, H. S. (2009). The State of Distance Education in Saudi Arabia. eLearn, 2009(10), 9. https://doi.org/10.1145/1626550.1642193

Arani, A. M. (2016). Researching Shadow Education in Iran: Methodological Experiences in an Islamic Republic Researching Private Supplementary Tutoring (pp. 133-146). Springer International Publishing.

Askar, P., \& Umay, A. (2001). Perceived computer self-efficacy of the students in the elementary mathematics teaching programme. Hacettepe University. The Journal of Education, 21(1-8).

Bandura, A. (1997). Self Edddicau The exercise of control. New York: Freeman.

Brosnam, M. J. (1998). The impact of computer anxiety and self-efficacy upon performance. Journal of Computer Assisted Learning, 14(3), 223-234. https://doi.org/10.1046/j.1365-2729.1998.143059.x

Busch, T. (1995). Gender Differences in Self-Efficacy and Attitudes Toward Computers. Journal of Educational Computing Research, 12(2), 147-158. https://doi.org/10.2190/H7E1-XMM7-GU9B-3HWR

Celik, V., \& Yesilyurt, E. (2013). Attitudes to technology, perceived computer self-efficacy and computer anxiety as predictors of computer supported education. Computers \& Education, 60(1), 148-158. https://doi.org/10.1016/j.compedu.2012.06.008

Chung, H.-N., Tu, Y.-L., \& Hsiao, H.-C. (2012). Perceived social supports, computer self-efficacy, and computer use among high school students. The Turkish Online Journal of Educational Technology, 11(2), 167-177.

Fives, H. (2003). What is teacher efficacy and how does it relate to teachers' knowledge? A theoretical review: The University of Maryland Paper presented at the American Educational Research Association Annual Conference, Chicago IL.

Gibson, C. C. (1996). Toward an understanding of academic self-concept in distance education. American Journal of Distance Education, 10(1), 23-36. https://doi.org/10.1080/08923649609526907

Gorder, L. (2008). A study of teacher perceptions of instructional technology integration in the classroom. Delta Pi Epsilon Journal, 50(2), 21-76.

Imhof, M., Vollmeyer, R., \& Beierlein, C. (2007). Computer use and the gender gap: The issue of access, use, motivation, and performance. Computers in Human Behavior, 23(6), 2823-2837. https://doi.org/10.1016/j.chb.2006.05.007

Isleem, M. (2003). Relationship of selected factors and the level of computer use for instructional purposes by technology education teacher in Ohio public school: A statewide survey (Doctoral dissertation). The Ohio State University.

Lowther, D. L., Inan, F. A., Daniel Strahl, J., \& Ross, S. M. (2008). Does technology integration "work" when key barriers are removed? Educational Media International, 45(3), 195-213. https://doi.org/10.1080/09523980802284317

Milheim, K. L. (2012). Cultural Inclusivity in Online Learning. In Student-Teacher Interaction in Online Learning Environments: IGI Global.

Miura, I. T. (1987). The relationship of computer self-efficacy expectations to computer interest and course enrollment in college. Sex Roles, 16(5-6), 303-311. https://doi.org/10.1007/BF00289956

Nordin, Z. S. O., A. E. A., \& Sam, H. K. (2005). Computer Self-Efficacy, Computer Anxiety, and Attitudes toward the Internet: A Study among Undergraduates in Unimas. International Forum of Educational Technology \& Society, 8(4), 205-219.

Papagianni, A., Bouta, H., \& Paraskeva. F. (2008). Individual characteristics and computer self-efficacy in secondary education teachers to integrate technology in educational practice. Computers \& Education, 50, 1084-1091. https://doi.org/10.1016/j.compedu.2006.10.006 
Paraskeva, F., Bouta, H., \& Papagianni, A. (2008). Individual characteristics and computer self-efficacy in secondary education teachers to integrate technology in educational practice. Computers \& Education, 50(3), 1084-1091. https://doi.org/10.1016/j.compedu.2006.10.006

Saadé, R. G., \& Kira, D. (2009). Computer anxiety in e-learning: The effect of computer self-efficacy. Journal of Information Technology Education, 8, 177-191.

Simsek, A. (2011). The Relationship between Computer Anxiety and Computer Self-Efficacy. Contemporary Educational Technology, 177-187.

Strickland, J., Powell, A., \& Ray, B. B. (2006). Technology Integration and the Preservice Teacher: A Roadmap for Reflection and Observation During Early Field Experiences. Teaching \& Learning, 21(1), 29-58.

Thompson Manning, D. (1987). Historical Lessons for Teacher Education. Journal of Teacher Education, 38(6), 20-24. https://doi.org/10.1177/002248718703800604

Webster, J., \& Martocchio, J. J. (1992). Microcomputer Playfulness: Development of a Measure with Workplace Implications. MIS Quarterly, 16(2), 201. https://doi.org/10.2307/249576

Witt, L., Powell, T., McNeill, S. J., Gainey, B. S., Aust, P. J., \& Carison, C. S. (2012). "Which Technology Should I Use to Teach Online?": Online Technology and Communication Course Instruction. MERLOT Journal of Online Learning and Teaching, 8(4), 334-347.

Yavuz, S. (2005). Developing a technology attitude scale for pre-service chemistry teachers. The Turkish Online Journal of Educational Technology, 4(1), 17-25.

\section{Copyrights}

Copyright for this article is retained by the author(s), with first publication rights granted to the journal.

This is an open-access article distributed under the terms and conditions of the Creative Commons Attribution license (http://creativecommons.org/licenses/by/4.0/). 